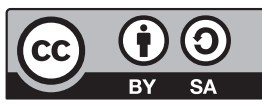

https://doi.org/10.31261/IJREL.2020.6.1.03

\title{
Svitlana Skvortsova
}

Ukraine

https://orcid.org/0000-0003-4047-1301

\section{Maryna Haran}

Ukraine

https://orcid.org/0000-0002-7438-126X

\section{Olena Sagan}

Ukraine

https://orcid.org/0000-0002-3195-3686

\section{Video Library of Mathematics Lessons as a Means of Methodological Training for Future Primary School Teachers}

\begin{abstract}
The authors substantiate the expediency of using video lessons and their fragments in the process of forming future teachers' professional competency. The elaborated library includes video recordings of real mathematics lessons at primary school and videos of pupils solving certain types of problems with full commentaries, structured by classes and topics. The methods of using the video library by educators in the field Methods of Teaching Mathematics in Primary School and students majoring in specialty 013 Primary Education were developed. The effectiveness of using the video library as a means of teaching the course Methods of Teaching Mathematics in Primary School was verified experimentally by introducing it into the educational process of three Ukrainian universities.

K e y w or d s: methods of teaching mathematics in primary school, a video fragment of a mathematics lesson, video library
\end{abstract}


The formation of methodological competency in teaching mathematics to students as one of the main components of professional competency of primary school teachers in Ukraine, takes place within the course of studying the discipline Methods of Teaching Mathematics. The conducted research (Verbytsky \& Bakshaeva, 1997; Skvortsova, 2015; Korol, 2005; Fritsko et al., 2007) and the practice of higher education in Ukraine proved the expediency of involving students in lectures, practical and laboratory classes in quasi-professional activities. In the process of quasi-professional activity, future teachers imitate certain elements of the teacher's activity by analysing, imitating, and reproducing the samples of primary school teacher's activity in standard and non-standard conditions. Definitely, students should systematically observe mathematics lessons at primary school, analyse them, determine the purpose of each stage of the lesson, the purpose of using certain tools and methods of teaching, the effectiveness of the teacher's actions and so on. It is possible to realise this need in practice only by attending mathematics lessons as a part of practicum period and in laboratory classes, which is not sufficient for the formation of future primary school teachers' methodological competency.

During lectures, students receive samples of future professional activities from the instructor, who analyses and simulates the activity of the teacher when considering a particular issue. In order for the instructor to be able to analyse the teacher's activity, students must first see how the teacher actually works, and this is possible by including certain fragments of lessons' videos in the content of the lecture.

In laboratory classes, observing the teacher's activity in real mathematics lessons, students present the results of their own analysis of the teacher's professional activity in teaching pupils certain topics of mathematics. Laboratory classes can be held both at school, where students observe a real mathematics lesson, and at university, as it is not always possible to arrange attending of mathematics lessons in a primary school within the schedule of the university classes. In addition, students must learn from the best examples of the teacher's methodological activity, which cannot always be provided at the school closest to the university. In this case, videos of real mathematics lessons in primary school or their fragments could be useful. In practical classes, students already have the opportunity to test themselves by imitating, playing situations related to the application of basic knowledge and methods of action, by familiarising themselves with new material, by the formation of concepts, skills and abilities. Thus, in order to organise laboratory classes conducted within the university, there is a need to provide opportunities for watching video recordings of mathematics lessons conducted by the best primary school teachers in Ukraine with their subsequent analysis. 
Video Library of Mathematics Lessons as a Means of Methodological Training...

Thus, a necessary foundation for students' quasi-professional activity is the observation of teachers' work in real mathematics lessons, which is possible both at school and at the university during laboratory classes. But, as evidenced by the analysis of normative programmes of the discipline Methods of Teaching Mathematics in Primary School in 12 higher education institutions of Ukraine, which we carried out within the framework of the summative experiment, 6 universities do not provide laboratory classes; their curriculum contains only lectures and practical classes. And this significantly reduces the possibility of involving students in the analysis of the best examples of primary school teachers' methodological activity. In this case, the importance of watching videos of real mathematics lessons in practical classes is growing.

Thus, the study of the course Methods of Teaching Mathematics requires those learning resources that create the opportunity to engage students in the analysis of mathematics lessons, and video recordings of real mathematics lessons conducted by the best primary school teachers could serve as such a tool.

The summative experiment also included a survey of 20 teachers of the subject Methods of Teaching Mathematics (K. Ushynskyi South Ukrainian National Pedagogical University, Kherson State University, Berdiansk State Pedagogical University, Vasyl Sukhomlynsky Mykolaiv National University, Vasyl Stefanyk Precarpathian National University and others); in the course of the experiment, it was found that a significant number of teachers use video materials (videos of mathematics lessons' fragments) both in the classroom (80\%) and in the process of students' self-guided work $(60 \%)$. Although almost all the teachers $(95 \%)$ are convinced that it is appropriate to use relevant videos, only about $20 \%$ of them do so regularly, which is obviously due to the lack of these video resources. Thus, only $10 \%$ of respondents confirmed that they already have all the necessary mathematics lessons' videos, and the rest ( $90 \%$ of teachers) would like to have a bank of such videos to facilitate students' mastery of the subject Methods of Teaching Mathematics in Primary School (illustrations of certain stages of lessons, application of learning technologies in mathematics lessons, various forms of work or certain methodological approaches, etc.) (Skvortsova, 2017).

The lack of a substantiated selection of mathematics lessons' videos at primary school and the objective need of lecturers in the field of Methods of Teaching Mathematics for specialty 013 Primary Education to use video materials, necessitated developing the video library of mathematics lessons at primary school and introducing it into the educational process in Ukraine.

It should be noted that despite the obvious methodological expediency of using lessons' video recordings in the process of mastering methodological disciplines by future teachers, the scientific literature still does not describe the experience of creating and using such teaching aids.

IJREL.2020.6.1.03 p. 3/20 
Thus, the researchers (Blomberg, Sturmer, \& Seidel, 2011; Masats \& Dooly, 2011; Gaudin \& Chalies, 2015; Noskova, Pavlova, Yakovleva, \& SmyrnovaTrybulska, 2017; Smyrnova-Trybulska et al., 2016; Seidel, Blomberg, \& Renkl, 2013; Christ, Arya, \& MingChiu, 2017) described general aspects of using video in pedagogical education. In the scientific and methodological literature we find some references concerning the use of video materials in lectures and practical classes on the methods of mainly secondary school in the form of videos showing physical or chemical experiments, reconstruction of historical events or videos with native speakers (Michael \& Sherry, 2019). Erica Litke's research is about using videos of algebra lessons in training future mathematics teachers. V. Zhelanova dwells upon the possibilities of using visualising lectures and provides an example of using "cut" fragments of video recordings of lessons in primary school within the framework of studying the subject Didactics of Primary School emphasising that it facilitates the perception of verbal, theoretical information by supporting visual impressions. Instead, the use of video recordings of mathematics lessons in primary school for methodological training of future teachers is somewhat neglected by scholars.

\section{Video Library of Mathematics Lessons in Primary School as a Means of Teaching "Methods of Teaching Mathematics"}

\subsection{Structure, Contents and Interface of the Video Library}

Based on the analysis of the Draft Sectoral Standard of Higher Education in specialty 013 Primary Education and the updated regulatory support of primary education (State Standard of Primary Education, Standard educational programmes), as well as Normative programmes of the subject Methods of Teaching Mathematics, in previous studies, we substantiated the expedient content of this academic subject (Skvortsova, 2015).

On the basis of the developed appropriate content of the subject, we determined the topics of mathematics lessons at primary school, which illustrate some issues of the Regulatory programme of the course, we selected primary school teachers from our, Southern, region of Ukraine, whose methodological activity in the field of teaching mathematics is worth following. The teachers of the institutions listed next agreed to take part in the experiment: teachers of the Nikolaev municipal board who are winners of the all-Ukrainian competition "Teacher of the year" (Hubanova T.O.), winners of regional competitions (Melnichuk L.I., Diomina T. M.), teachers and teacher trainers (Shelim O. I., Yukhymuk T.P.). We also recorded the process 
Video Library of Mathematics Lessons as a Means of Methodological Training...

of solving certain types of tasks by the college students with full commentaries. At the same time, of great interest for teaching the course Methods of Teaching Mathematics are videos of lessons of the best primary school teachers in Ukraine, which were presented at the All-Ukrainian competition "Teacher of the year".

According to the topics and subtopics determined in the content of the discipline (S. Skvortsova, 2017), all these videos were divided into fragments in order to illustrate certain aspects of lectures, practical/laboratory classes, and thus to create a video library of mathematics lessons at primary school and their fragments.

The developed video library is located in the electronic course Methods of Teaching the Educational Branch "Mathematics", created in the system of distance learning of the Kherson State University "KSU Online" (http://ksuonline.kspu. edu/course/view.php?id=1078) (Figure 1).
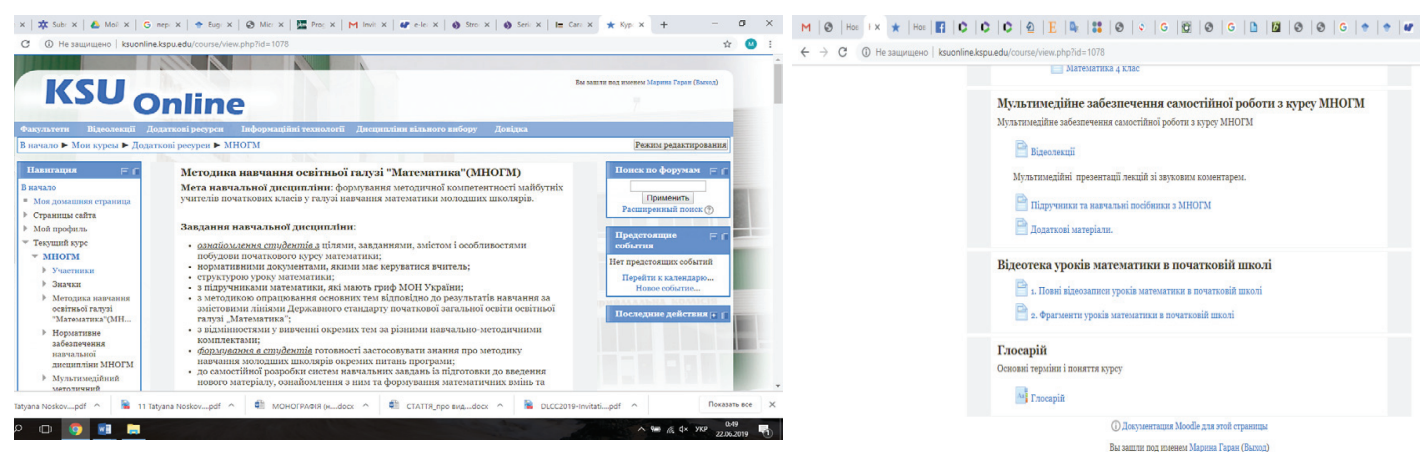

Bamerou

Figure 1. Location of a video library of mathematics lessons at primary school on the site of "KSU Online"

S o u r c e: Own work.

The course Methods of Teaching Mathematics is structured by sections, which in turn, may contain several topics. Thus, the first section contains one topic: "Methodological system of teaching mathematics to primary school pupils." The following subtopics form the content of this topic: 1. Methods of teaching mathematics as a science and as a subject. 2. The aim and objectives of teaching mathematics in primary school under the new version of the State Standard of Primary Education (2018). 3. The content of teaching mathematics at primary school. Typical educational programme for years 1-2 (2018); 3-4 (2019). 4. Methods and forms of teaching mathematics in primary school. Modern educational technologies in teaching mathematics in primary school. Lesson model built according to different learning technologies. 5. Means of teaching mathematics in primary school. 
Obviously, not all the aspects of the topic should be accompanied by illustrations. The video library presents video clips that illustrate only questions 4 and 5 of the topic. Moreover, methods, forms of teaching, technologies and teaching aids are illustrated by several fragments of lessons on different topics of mathematics in the grades $1-4$, which creates an opportunity for teachers of the subject Methods of Teaching Mathematics to choose a video based on their own lectures and preferences. In the video library there are fragments of applied problem-searching teaching methods, interactive technology of training; videos illustrating the work with various teaching aids in mathematics - visual aids and didactic materials (for example, textbooks, exercise books, multimedia presentations, valuable material by M. Montessori, Cuesser sticks, dominoes, sets of geometric shapes, Lego bricks, etc.).

The second section also contains one topic: "Modern mathematics lesson in primary school." The topic includes the following subtopics: 1. Calendar and thematic planning of mathematics lessons. 2. The purpose and objectives of mathematics lessons. 3. The structure of the combined lesson of mathematics. 4. Motivation of pupils' educational and cognitive activity. 5. Application of basic knowledge and students' ways of acting. 6 . Familiarisation with new educational material and its mastering. 7. Consolidation. Formation of skills and abilities. 8. Reflection on students' educational and cognitive activity in the classroom.

This topic is also properly presented in the video library, in particular, subtopics 4-8 are illustrated by various video fragments that demonstrate the variability of certain stages of mathematics lessons at primary school (Figures 2 and 3).

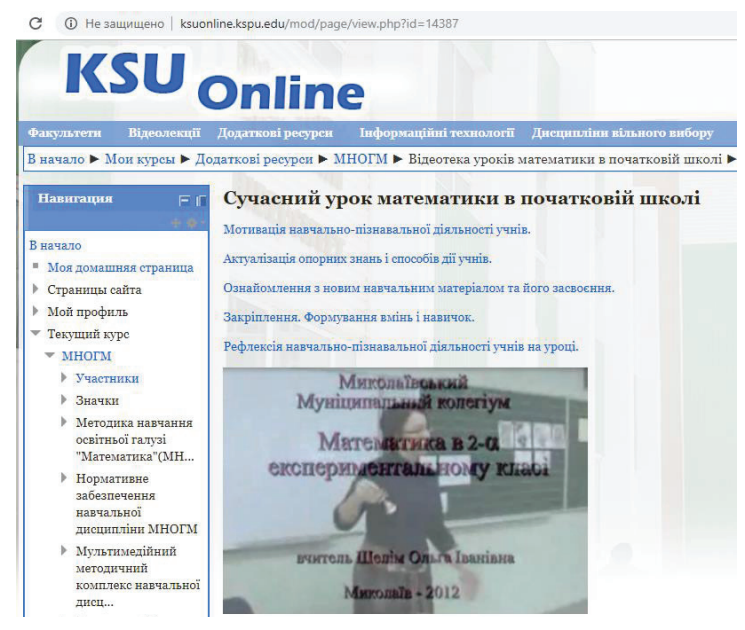

Figure 2. The section of the video library: "Modern mathematics lesson in primary school" S ou r ce: Own work.

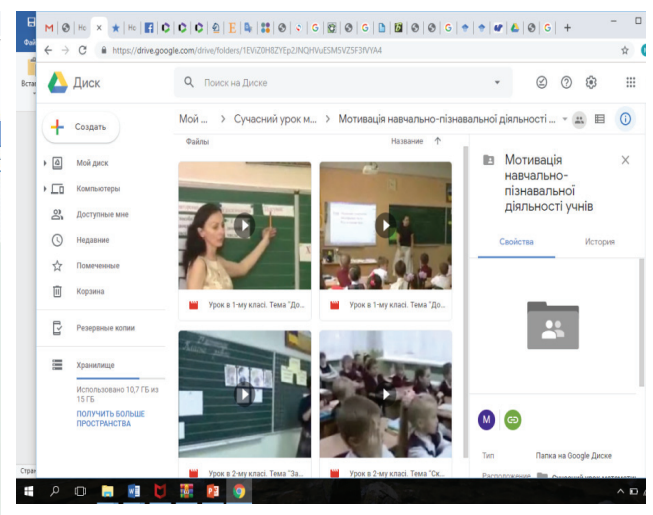

Figure 3. Content of the subsection "Motivation of pupils' educational and cognitive activity" in the second section of the video library S o u r c e: Own work. 
Video Library of Mathematics Lessons as a Means of Methodological Training...

The third section is divided into six subsections, each of which contains several topics.

1. Methods of realising and systematising mathematical knowledge of the firstyear pupils obtained in the preschool period.

2. Methods of teaching counting and arithmetic operations on numbers in the course of elementary mathematics. This section provides a study of several topics: "Methods of teaching the first ten counting numbers"; "Methods of forming computational skills of addition and subtraction within 10"; "Methods of teaching the first hundred counting numbers"; "Methods of forming computational skills of addition and subtraction within 100 not crossing the boundary"; "Methods of forming computational skills of addition and subtraction within 20 with crossing the boundary"; "Methods of forming computational skills of addition and subtraction within 100 with crossing the boundary"; "Methods of computational skills of table multiplication and division"; "Methods of studying the counting numbers in the concentre? "Thousand"; "Methods of forming computational skills of addition and subtraction within 1000"; "Methods of forming computational skills beyond table multiplication and division"; "Methods of teaching multi-digit numbers counting"; "Methods of forming computational skills in the concentre? 'Multidigit numbers"'; "Methods of forming the understanding of the concept "parts of value" "; "Methods of forming the understanding of the concept of fraction" (Skvortsova, \& Haran, 2017). Additionally, each of the topics is explained in a system of aspects: 1) the content and learning outcomes of the topic according to the Standard curriculum; 2) visual aids and didactic material; 3) the procedure for studying the topic according to current textbooks; 4) methods of teaching certain aspects of the topic; 5) implementation of the new curriculum's content in existing textbooks.

These topics include video recordings of the lessons on updating the basic knowledge and ways of pupils' activity, creating and solving a problem situation, pupils discovering possible way of solving the problems, as well as video recordings of pupils performing certain calculations. Thus, the teacher can include certain video fragments in the content of the lecture if necessary. In practical classes, the teacher can use videos of pupils solving certain problems both to motivate students' learning activity and to analyse and evaluate students' problem-solving skills (e.g. Figure 4). 


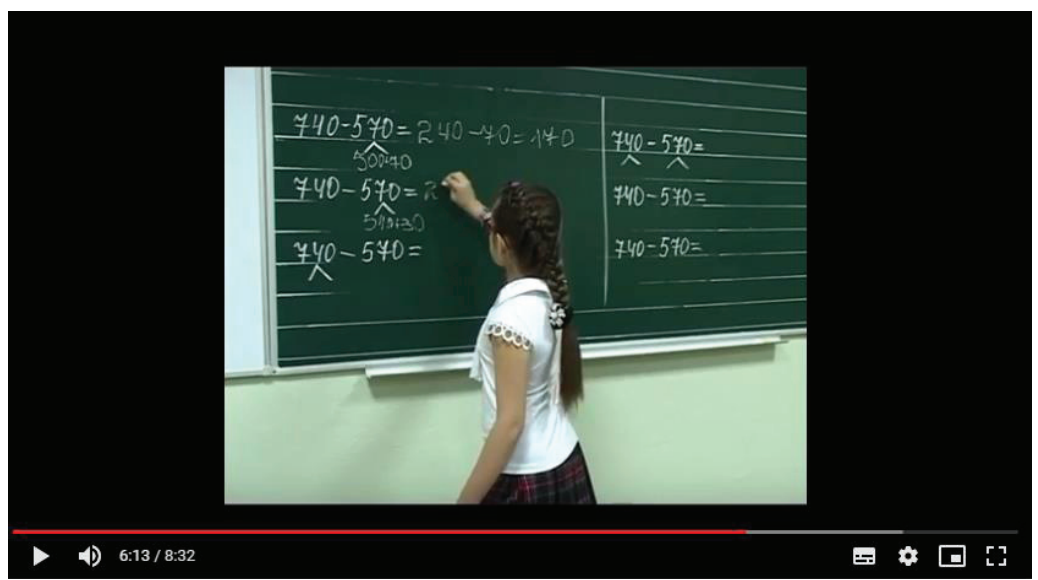

Figure 4. Video fragment of problem solving including applying the methods of calculation within a thousand

S o u r c e: Own work.

3. The subsection "Methods of teaching values and their measurement" covers the following topics: "Methods of teaching basic values and their measurement: length, weight, capacity; time," "Area of the figure." The content of the first topic unfolds in several subtopics: 1) Values in the course of elementary mathematics; 2) Learning content and outcomes; 3) Methods of studying certain topics of the curriculum: 1st grade, 2 nd grade, 3rd grade, 4th grade. It is the last topic that is illustrated in the video library by video recordings of mathematics lessons in different classes of primary school, during which pupils learn about certain values.

4. "Methods of teaching mathematical expressions, equations and inequalities." The subsection is focused on the topic: "Algebraic material in the course of elementary mathematics." Its content is reflected in the following subtopics: 1) The content of the algebraic material of elementary mathematics; 2) Mathematical expressions: numeric and alphanumeric; 3) Numerical equality and inequality: the dependence of the result of the arithmetic action on the change of the component; 4) The equation; 5) Solving problems using equations; 6) Inequality with a variable.

Here, besides the videos of teacher's methodological activity, there are interesting videos of pupils' comments on solving simple and complex equations (equations in which the right part is represented by a numerical expression, equations in which one of the components is represented by a numerical expression, equations in which one of the components is given as the expression with a variable), pupils' video comments on solving inequalities with one variable in different ways. 
Video Library of Mathematics Lessons as a Means of Methodological Training...

5. The subsection: "Methods of teaching the solving of mathematical word problems" represents the following topics: "Methods of teaching the solving of mathematical word problems: general questions," "Methods of forming the skills of solving simple mathematical problems in the 1st grade"; "Methods of forming the skills of solving simple mathematical problems in the 2nd grade"; "Methods of introducing the concept of 'a complex mathematics problem"'; "Methods of forming the skills of solving simple mathematical problems in the 3rd and 4th grades"; "Methods of forming the skills of solving complex mathematical problems in the 3rd grade"; "Methods of forming the skills of solving mathematical problems finding 4-th proportional"; "Methods of forming the skills of solving mathematical problems on a double conversion to one"; "Methods of forming the skills of solving mathematical problems on proportional division," "Methods of solving the mathematical problem on finding unknown by two differences"; "Methods of forming the skills of solving mathematical problem for joint work"; "Methods of forming the skills of solving problems on the movement."

The content of each topic, which relates to the methods of forming the skills for solving typical problems, covers several subtopics: 1) the content and results of learning the topic of the new curriculum; 2) the content and methods of preparatory work; 3) introduction of a new type of tasks; 4) formation of the ability to solve problems.

In lectures and laboratory classes, teachers can use the following video clips: "Introducing simple problems to first-year pupils," "Introducing inverse problems to first-year pupils," "Introducing complex problems to second-year pupil," "Work on complex tasks," etc. In practical classes, to analyse and evaluate pupils' activity on solving simple and complex, including typical, problems, teachers can offer students to watch videos of real pupils solving them.

6. The subsection "Methods of teaching spatial relations and geometric figures," contains the topic: "Methods of teaching elements of geometry in the course of elementary school mathematics," which is studied through the following subtopics: 1) the content of the geometric material of the elementary mathematics course; 2) the order of studying the elements of geometry at primary school; 3) methods of forming geometric ideas and concepts: about a point, a line, a curve, a segment, and a broken line; polygons and their elements; an angle, types of angles; a rectangle and a square; a circle, a round and their elements; geometric shapes in space. This topic is illustrated in the video library by some video fragments: "Forming the idea about a point, a line, a curve, a segment and a broken line"; "Forming the idea about polygons and their elements"; "Forming the idea about an angle, types

IJREL.2020.6.1.03 p. 9/20 
of angles"; "Forming the idea about a rectangle and a square"; "Forming the idea of a circle, a round and their elements"; "Geometric shapes in space."

When developing the interface for the created video library, we proceeded from the need to provide teachers of the subject Methods of Teaching Mathematics in Primary School with the opportunity to work with both full-length videos of mathematics lessons and their fragments. Therefore, the structure of the video library contains two blocks: (1) Full-length videos of mathematics lessons at primary school. (2) Fragments of mathematics lessons at primary school. Both blocks are structured in accordance with the sections and topics determined by the content of the subject Methods of Teaching Mathematics in Primary School. The second block, which contains fragments of lessons, is also structured according to corresponding aspects of the topic. The interface consists of a list of sections, topics and subtopics, which, with the help of hyperlinks, redirects the teachers to the video file they need.

\subsection{Checking the Efficacy of UsingVideo Library Materials in Forming Future Teachers' Methodological Competency}

At the formative stage of the experimental study (2016-2018,) teachers of the subject Methods of Teaching Mathematics of Kherson State University, Vasyl Stefanyk Precarpathian National University, and K. Ushynskyi South Ukrainian National Pedagogical University, who were part of the experimental group, used the proposed materials of the video library in the classroom and offered them for students' self-guided work. The teachers of the subject Methods of Teaching Mathematics of Izmail State Humanities University, Berdiansk State Pedagogical University, Vasyl Sukhomlynsky Mykolaiv National University, who formed the control group of the study, used only their own materials in the educational process.

Thus, it was sufficient for the teachers of the experimental group, when preparing for the lecture, to find out, in accordance with the topic of the lesson, which topics should be illustrated with video material, and to choose from the video library the necessary lesson or video recording of pupils solving certain problems. The teacher had the opportunity to use either full-length video or its fragment using the materials of the first or second block of the video library, respectively. In addition, if there was a need to demonstrate part of the fragment, the lecturer could turn on the video from the particular moment (e.g., they could show not the whole fragment, but only part of it from 3:45 to 7:28), or edit (cut out) the required fragment of the video file using special applications (e.g., Windows Movie Maker (Smyrnova-Trybulska, 2016) (had there been an appropriate software on the computer), or by using online services such as Online Video Cutter, etc.) and add it to the lecture. 
Video Library of Mathematics Lessons as a Means of Methodological Training...

During the practical classes, the teachers of the experimental group used the materials of the video library both as material for analysing the structure of classes and teacher's activity, and to illustrate methodological approaches for mastering a particular concept or skill or in implementing a particular learning technology as a sample of activity for future teachers. In addition, teachers used video fragments of classes to motivate students' learning activity.

Using video fragments of mathematics lessons at primary school, the teacher formulated a learning task: to analyse and evaluate the teacher's activity on organising certain stages of the lesson.

Using video recordings of mathematics lessons at primary school, the teacher implemented another learning task: to assess the correctness of the solution and the completeness of its explanation by the pupil.

To perform, in course of self-guided work, tasks such as "Prepare a lesson plan and summary" or "Develop systems of learning tasks," students were offered to view video fragments of mathematics lessons at primary school as an example of implementing a plan or the system of learning tasks etc. Analysing the lesson after watching the video in the process of self-guided work, students were asked to answer the questions, such as: What is the purpose and didactic task set by the teacher for the lesson?; What is the developmental and educational task of the lesson?; What type of lesson it is?; What educational content they consolidated at the stage of applying basic knowledge?; What is the need for its application?; How the teacher organised the stage of introducing new material and methods of performing tasks?; What methods and technologies he/she used?; What educational content was offered by students at the consolidation stage?; Formation of skills and abilities; what forms of work were used by the teacher at this stage?; What was the work of students in the classroom like (activity, independence, desire to work, correct answers)?; How the teacher summed up the lesson?; Whether the teacher has solved the tasks of the lesson?; What are students' personal impressions from the lesson?; What is needed to conduct lessons at a high level?; What is the purpose of mastering the course Methods of Teaching Mathematics?; What tasks students face during the study of mathematics?, etc.

Teachers of the control group noted that they did not use lessons' video fragments in teaching the subject Methods of Teaching Mathematics in Primary School or used them only from time to time, if any were available.

At the end of teaching the course, in order to check the effectiveness of the created video library a survey of teachers was carried out. During the interview, the teachers of the experimental group mentioned the convenience of using the video library and facilitation of the process of preparing a lecture, practical or laboratory lesson; they much more often illustrated methodical approaches, technologies and 
methods of teaching with video recordings. Teachers of the control group claimed that they had difficulties in selecting video recordings of lessons, so they more often declined the opportunity to use video materials.

Summing up the results of the survey, we found that according to the teachers of the experimental groups, the quality of lectures and practical classes had increased due to the practical orientation of their content, emotional impact on students, they promoted the formation of students' cognitive interest in mastering methods of teaching mathematics at primary school. They underlined a more meaningful perception of educational material by students; students noted that the use of video fragments of mathematics lessons contributed to a better memorisation of learning content due to the opportunity to reproduce and imitate the teacher's activity. The organisation of educational activity for mastering the subject Methods of Teaching Mathematics using the video library materials helped students to obtain algorithms and quasi-algorithms for solving methodological problems that arise in the process of teacher's methodological activity. According to the teachers of the experimental group, the demonstration of video fragments of real mathematics lessons at primary school facilitates the application of knowledge of the subject Methods of Teaching Mathematics in practice - in direct professional activity. Thus, due to watching and analysing the video fragments of mathematics lessons at primary school, due to the involvement of students in quasi-professional activity during practical and laboratory classes, students' practical readiness to teach pupils mathematics, in particular, a special methodological component of methodological competency is formed (Skvortsova, 2017).

In addition to interviewing the teachers of the course Methods of Teaching Mathematics," in order to determine the level of future primary school teachers' methodological competency, including its special and methodological, projecting and modelling, controlling and evaluative components, according to set criteria and indicators, a control check was conducted among students of specialty 013 Primary Education at the universities selected by us as experimental and control institutions.

We will present only generalised criteria for the formation of future primary school teachers' methodological competency in teaching mathematics at primary school.

The motivational criterion - characterises the level of formation of internal motives and motivations, aspirations for perfect professional activity in teaching mathematics, interest in professional activity, desire for professional growth and creativity in teaching mathematics to primary school pupils in future primary school teachers. The content criterion characterises the degree of future teacher's mastery of methodological knowledge on teaching mathematics to primary 
Video Library of Mathematics Lessons as a Means of Methodological Training...

school pupils. The operational and activity-oriented criterion marks the level of future primary school teacher's mastery of the system of methodological abilities and skills necessary for successful teaching mathematics to pupils; ability to construct and design mathematics lessons, use modern pedagogical technologies and introduce innovative approaches to teaching junior pupils mathematics.

Among the generalised indicators that reflect each of the described criteria, it is worth mentioning: motivational criterion, reflected in the desire of the future primary school teacher to perfect professional activity in teaching mathematics; content criterion - through methodological knowledge; operational and activityoriented criterion - through methodological skills.

According to the outlined criteria and indicators, for each component of methodological competency four levels of formation of future primary school teacher's methodological competency are described: low, average, sufficient, high. Here are the generalised levels of formation of future primary school teacher's methodological competency in teaching pupils mathematics:

- low level - characterised by a lack of desire for perfect methodological activity on teaching pupils mathematics (motivational criterion), fragmentary methodological knowledge, skills that are insufficient to perform professional functions (content and operational criteria);

- average level, which is characterised by situational or poorly expressed desire to effectively teach mathematics to primary school pupils (see motivational criterion), partial mastery of methodological knowledge, unconscious and non-generalised skills to apply acquired knowledge, ability to work only according to the model or with the help of the teacher, etc. - activity-oriented criterion;

- sufficient level, which is characterised by a strong desire for effective teaching mathematics to primary school pupils (motivational criterion), the presence of complete, generalised knowledge of methodology, the skills and ability to apply it independently in educational, cognitive and practice-oriented situations (content and operational criteria);

- high level, which is characterised by the desire to creatively implement the acquired knowledge and skills in the process of teaching mathematics to primary school pupils (motivational criterion), creative approach to teaching primary school pupils mathematics and the ability to create innovative methodological approaches (content and operational criteria).

Check of the outlined levels of methodical competency's formation took place in the form of testing. The control check contained three tests, each of them involved determining the level of formation of special and methodological, projecting and modelling, control and evaluative components of methodological competency. It should be noted that we understand special and methodical

IJREL.2020.6.1.03 p. 13/20 
component as the ability to form in pupils all the elements of the subject's content, which is based on students' theoretical and practical readiness to teach any topic of the curriculum. The control and evaluative component of future primary school teachers' methodological competency manifests itself in the teacher's readiness to implement the criteria for assessing student's achievement and the ability to adequately assess student's achievement. The projecting and modelling component of the teacher's methodological competency is understood as the ability to design the learning process of the subject during the school year, to design lessons according to different teaching and methodological kits, in accordance with modern requirements, the ability to model teacher and pupil activities at each stage of the lesson aimed at achieving learning outcomes (Skvortsova S.).

Each test included both close-ended tasks involving the selection of one or more correct answers (mostly reproductive and partially productive), and open (partially productive, productive, and creative). Each test contained two options of five questions.

Testing confirmed a slightly higher level of indicators of the special and methodological component within the methodological competency of students in the experimental group, compared with the control one (Figure 5).

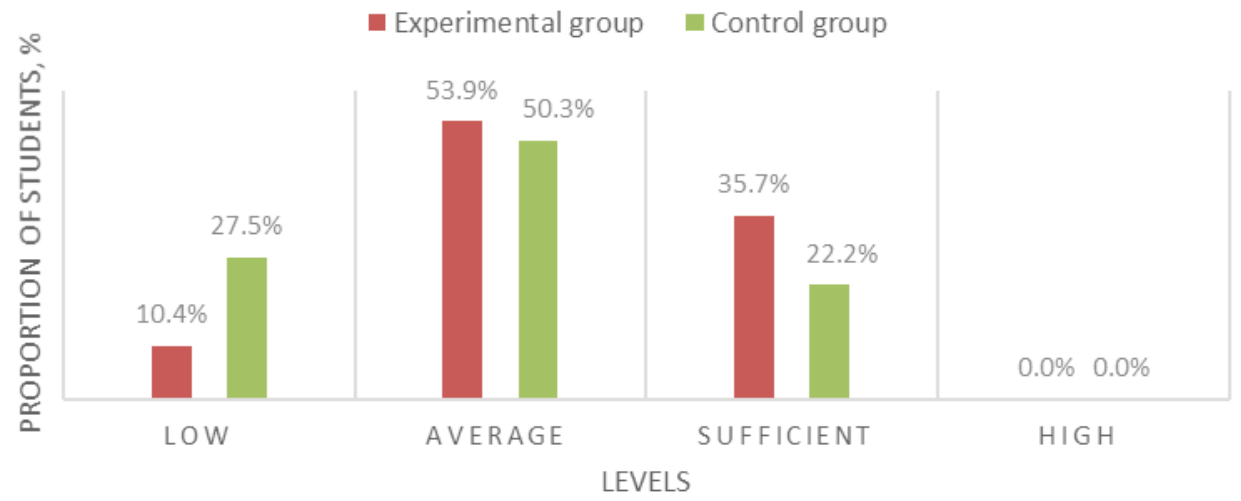

Figure 5. Distribution of experimental and control group students by the levels of formation of methodological competency's special and methodological component S ou r c e: Own work.

Moreover, teachers noted that they noticed some influence, due to the possibility of using video fragments of mathematics lessons or videos demonstrating the thoughts of real pupils, on the formation of the control and evaluative component of future primary school teachers' methodological competency. Thus, there is an opportunity for students in the course of practical/ laboratory classes when watching video fragments of lessons with pupils solving 
Video Library of Mathematics Lessons as a Means of Methodological Training...

certain problems, to evaluate pupils' answers implementing the criteria for assessing their performance. It should be noted that the control and evaluative component of the methodological competency is usually formed mainly during the direct practical training of students - during pedagogical internship, so video fragments of lessons create certain prerequisites for the formation of this component during practical/laboratory classes.

At the same time, the teachers of the control group stated that they have almost no opportunity to form the control and evaluative component of students' methodological competency in the classroom. And the students themselves, as testing showed, demonstrated a low level of implementing the criteria for assessing pupils' achievements in mathematics. Instead, students whose teachers of the experimental group worked with using the materials of the video library, showed a relatively higher level of this indicator's formation (Figure 6).

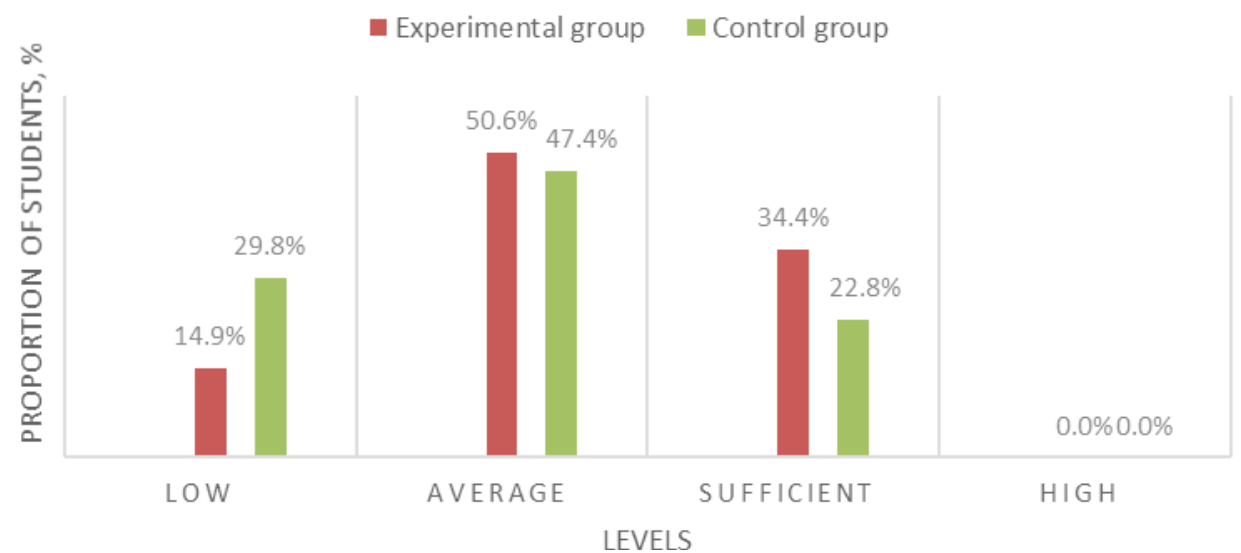

Figure 6. Distribution of experimental and control group students by the levels of the formation of methodological competency's control and evaluative component S o u r c e: Own work.

Thus, the results of the study showed an increase in the level of the projecting and modelling component's formation in students of the experimental group (Figure 7). The students of the experimental group revealed a more thorough knowledge of the methods of organising pupils' activity and managing these activity in the process of teaching mathematics to primary school pupils; methods, forms, and means of teaching mathematics to primary school pupils, as well as the ability to select them. In addition, students who regularly had the opportunity to watch video fragments of real mathematics lessons, showed the ability to create projects of mathematics lessons according to different teaching kits.

IJREL.2020.6.1.03 p. $15 / 20$ 


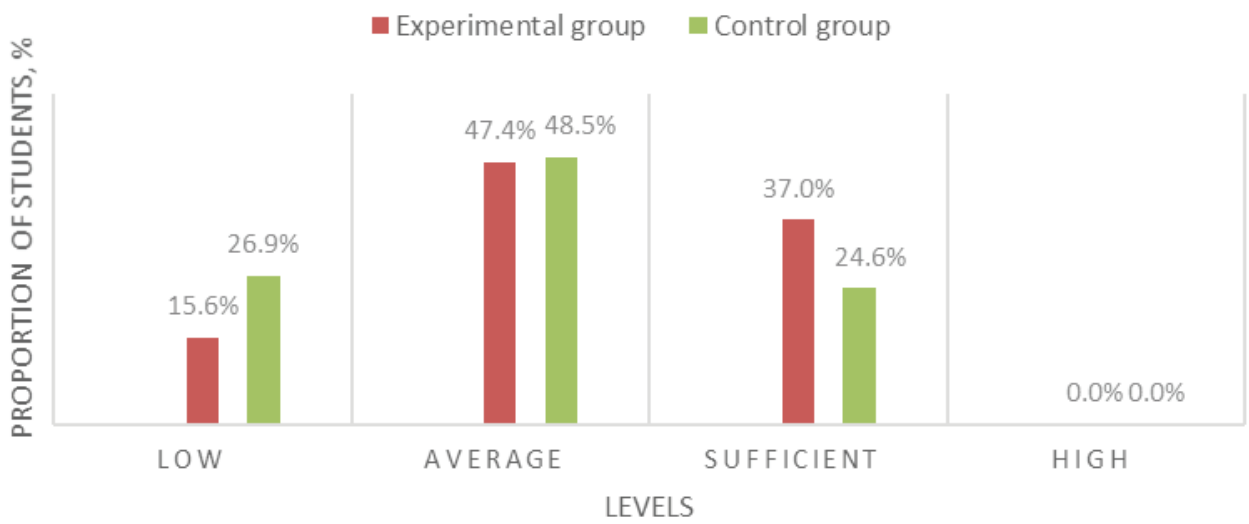

Figure 7. Distribution of experimental and control group students by the levels of formation of methodological competency's projecting and modelling component S o u r c e: Own work.

Thus, the study confirmed the positive impact of the developed video library on the formation of future primary school teachers' methodological competency, in particular its special and methodological, control and evaluative, projecting and modelling components.

It is also worth noting that both teachers and students emphasise that the use of video fragments of real mathematics lessons in mastering the methodology of teaching mathematics generated special positive emotions stimulating positive attitude to the subject Methods of Teaching Mathematics and, among other things, contributed to the development of students' professional motives.

\section{Conclusions}

The study substantiates the expediency of using a video library in forming future teachers' professional/methodological competency. The authors created a video library which includes video fragments of real mathematics lessons at primary school and videos of pupils solving certain types of problems with their full commentaries, structured by classes and topics. The videos are divided into topics of the course Methods of Teaching Mathematics and are presented in a userfriendly interface, which is a list of topics and subtopics and which allows to go by the appropriate video links to the video required. The video library is located within the e-course "Teaching methods of the educational field 'Mathematics'," 
Video Library of Mathematics Lessons as a Means of Methodological Training...

which operates in the distance learning system of "KSU Online" on the website of Kherson State University. The method of using the video library by teachers of the subject Methods of Teaching Mathematics in Primary School and students majoring in the specialty 013 Primary Education was developed. The materials of the video library were introduced into the educational process of the three institutions of higher education of Ukraine: Kherson State University, Vasyl Stefanyk Precarpathian National University and K. Ushynskyi South Ukrainian National Pedagogical University.

Teachers of the subject Methods of Teaching Mathematics in Primary School used video materials in the classroom to illustrate methodological approaches to teaching students a separate concept or forming skills in them, as well as during the implementation of a particular learning technology, etc.; as a material for analysing the structure of the lessons and teacher's methodological activity; as an example of a teacher's activity; with the aim of motivating students' educational activity, etc.

Working with the materials of the video library during their self-guided work, students were able to analyse the teacher's activity, to find out the purpose of the pedagogical influences that they used at certain stages of the lesson, and choose the most attractive pedagogical strategy for constructing a mathematics lesson and organising communication with students. The effectiveness of using video recordings of mathematics lessons and videos of students' thoughts when solving certain problems that are part of a video library as a means of studying the course Methods of Teaching Mathematics in Primary School is confirmed experimentally.

According to the results of the study, it was found that a video library of mathematics lessons in the grades 1-4 and their fragments illustrating the relevant element of educational content (lesson structure, learning technologies, etc.), as well as videos with students thinking over some problems which show calculation methods, work on problems etc. is an effective means of teaching the course Methods of Teaching Mathematics in Primary School.

\section{References}

Blomberg, G., Sturmer, K., \& Seidel, T. (2011). How pre-service teachers observe teaching on video: Effects of viewers' teaching subjects and the subject of the video. Teaching and teacher education, 27, 1131-1140.

Christ, T. Arya. P., \& MingChiu, M. (2017).Video use in teacher education: An international survey of practices. Teaching and Teacher Education, 63, 22-35.

IJREL.2020.6.1.03 p. 17/20 
Fritzko, J.S. (2007). Quasiprofessional activity in the preparation of future teachers in the conditions of the pedagogical college. Internet magazine "Eidos". Retrieved from http: www.eidos.ru/ joumal/2007/0930-24.htm.

Gaudin, C., \& Chalies, S. (2015). Video viewing in teacher education and professional development: A literature review. Educational research review, 16, 41-67.

Haran, M., Sagan, O., \& Liba O. (2018). Formation of methodological and informational competence of the primary school teacher. Information Technologies and Learning Tools, 3, 304-315.

Korol, B. (2005). Quasiprofessional activity in the process of preparing future teachers. Retrieved from http://www.nbuv.gov.ua/old_jrn/Soc_Gum/Vchu/N135/p096-101.pdf.

Litke, E. (2019). The Nature and Quality of Algebra Instruction: Using a Content-Focused Observation Tool as a Lens for Understanding and Improving Instructional Practice, Cognition and Instruction, DOI: 10.1080/07370008.2019.1616740.

Masats, D., \& Dooly, M. (2011). Rethinking the use of video in teacher education: A holistic approach. Teaching and Teacher Education, 27, 1151-1162.

Michael B., Sherry, Lauriann M., Messier-Jones \& Joanelle, Morales (2018). Positioning in prospective secondary English teachers' annotations of teaching videos. English Teaching: Practice \& Critique, 17, 152-167.

Noskova, T., Pavlova, T., Yakovleva, O., \& Smyrnova-Trybulska E. (2017). Programmed and audiovisual learning - the stages of information technology implementation in the educational practice . Edukacja Humanistyczna, 2, 123-137.

Seidel, T., Blomberg, G., \& Renkl, A. (2013). Instructional strategies for using video in teacher education. Teaching and Teacher Education, 34, 56-65.

Skvortsova S. (2015). Formation of methodical competence of future teachers through the academic discipline «Methodology of teaching mathematics». Psychologist Pedagogy specială Asistenţă socială, 24-32.

Skvortsova S., \& Haran M. (2015). Preparation of future primary school teachers for studying mathematics students. Mountain School of the Ukrainian Carpathians, 12-13, 209-215.

Skvortsova, S., \& Haran, M. (2017). Training for primary school teachers in teaching mathematics using information technologies. Effective Development of Teachers' Skills in the Area of ICT and E-learning, Scientific Monograph edited by Eugenia Smyrnova-Trybulska, 9, 414-439. ISSN: 2451-3644 (print edition) ISSN 2451-3652 (digital edition) ISBN 978-83-60071-96-0.

Skvortsova, S., \& Haran, M. (2018). The constructor of multimedia lecture presentations as a means of studying the discipline «Methodology of teaching mathematics at primary school». E-learning and Smart Learning Environment for the Preparation of New Generation Specialists. Monograph Scientific Editor Eugenia Smyrnova-Trybulska, 10, 531-549.

Smyrnova-Trybulska, E., Ogrodzka-Mazur, E., Szafrańska-Gajdzica, A., Drlík, M., Cápay, M., Tomanová, J., Švec, P., Morze, N., Makhachashvili, R., Romanyukha, M., Nakazny, M., Sorokina, L., Issa, Tomayess, \& Issa, Theodora. (2016). Recommended Applications for Making Presentations and Didactic Videos. Some Research Results. DIVAI 2016 - Distance Learning in Applied Informatics (pp. 235-246). ISBN 978-80-7552-249-8. ISSN 2464-7470 (Print) ISSN 2464-7489 (On-line).

Verbitsky, A.A, \& Bakshaeva, N.A. (1997). The problem of the transformation of motives in contextual learning. Questions of psychology, 3, 17-19.

Zhelanova, V. (2012). Lecture of contextual type as a form of organization of training in the system of professional training of the future primary school teacher in the university. Scientific herald of Uzhgorod National University. Series: Pedagogy. Social work, 24, 48-52. 
Video Library of Mathematics Lessons as a Means of Methodological Training...

Svitlana Skvortsova, Maryna Haran, Olena Sagan

\section{Wideobiblioteka lekcji matematyki jako środek metodycznego przygotowania przyszłych nauczycieli szkół podstawowych}

Streszczenie

W artykule uzasadniono celowość wykorzystania nagrań lekcji i/lub ich fragmentów w procesie kształtowania kompetencji zawodowych przyszłych nauczycieli. Utworzono bibliotekę wideo, która zawiera filmy prezentujące lekcje matematyki w szkole podstawowej oraz filmy instruktażowe dotyczące rozwiązywania określonych rodzajów zadań przez uczniów, a także komentarze metodyczne i merytoryczne, ułożone według klas i tematów. Opracowano strategię wykorzystania biblioteki wideo dla nauczycieli nauczania matematyki w szkole podstawowej oraz program szkolenia nauczycieli w zakresie edukacji matematyki w szkole podstawowej. Skuteczność wykorzystania biblioteki wideo jako środka do studiowania kursu „Metody nauczania matematyki w szkole podstawowej" została potwierdzona eksperymentalnie poprzez trzy uniwersytety w Ukrainie, które włączyły ten kurs do programu studiów.

Słow a kluczowe: metoda nauczania matematyki w szkole podstawowej, zapis wideo lekcji matematyki, biblioteka wideo

Светлана Скворцова, Марина Гаран, Елена Саган

\section{Видеобиблиотека уроков математики как средство методической подготовки будущих учителей начальной школы}

Анн о т а ц я

Обоснована целесообразность использования видеозаписей уроков и их фрагментов в процессе формирования профессиональной компетентности будущих учителей. Создана видеотека, которая включает в себя видео реальных уроков математики в начальной школе

и видеофильмы о решении определенных типов задач учениками с их полным комментарием, которые структурированы в соответствии с классами и темами. Разработана методика использования видеотеки для учителей методики преподавания математики в начальной школе и программы подготовки учителей начального образования. Эффективность использования видеобиблиотеки как средства изучения курса «Методика преподавания математики» в начальной школе подтверждается экспериментально путем внедрения в учебный процесс трех вузов Украины.

К л ю ч е в ы е с л о в а: методика преподавания математики в начальной школе, видеозапись занятий по математике, видеотека 
Svitlana Skvortsova, Maryna Haran, Olena Sagan

\title{
Video biblioteca de lecciones de matemáticas como medio de preparación metodódica de futuros profesores de escuela primaria
}

\author{
Resumen
}

Se confirma la conveniencia de utilizar la grabación de video de las lecciones y sus fragmentos en el proceso de formación de la competencia profesional de los futuros maestros. Se ha creado una videoteca, que incluye el video de lecciones reales de Matemáticas en la escuela primaria y videos de resolución de ciertos tipos de tareas de los alumnos con sus comentarios completos, que están estructurados de acuerdo con las clases y los temas. Se desarrolla la metodología de uso de la videoteca para docentes de metodología de enseñanza de las matemáticas en la escuela primaria y el programa de formación docente de Educación Primaria. La efectividad del uso de la videoteca como medio para estudiar el curso „Métodos de enseñanza de las matemáticas” en la escuela primaria se confirma experimentalmente al introducirse en el proceso educativo de tres universidades de Ucrania.

Pa labra s clave: método de enseñanza de las matemáticas en la escuela primaria, grabación de video de lecciones de matemáticas, videoteca 